\title{
An Analysis of the Relevance of Off-Balance Sheet Items in Explaining Productivity Change in European Banking
}

\author{
Barbara Casu $^{\dagger}$ \\ The University of Reading \\ Claudia Girardone ${ }^{* *}$ \\ University of Essex
}

\begin{abstract}
The 1990s have witnessed a significant growth in bank income generated through non-traditional activities especially for large EU universal institutions. Using the non-parametric Malmquist methodology this paper analyses the importance of the inclusion of off-balance sheet (OBS) business in the definition of banks output when estimating total factor productivity change indexes. The analysis is then extended to the decomposition of total factor productivity change into technical efficiency and technological change. The results reinforce the prevalent view in the recent literature, indicating that the exclusion of non-traditional activities leads to a misspecification of banks output. In particular, the inclusion of OBS items results in an increase in estimated productivity levels for all countries under study. However, the impact seems to be the biggest on technological change rather than efficiency change. Overall, results suggest that despite the uneven distribution of OBS between countries and among different institutions in the same country, these non-traditional activities are increasingly important and failure to account for them would lead to biased conclusions.
\end{abstract}

JEL classification: G21; D24.

Keywords: Finance and Banking; Productivity Change; Malmquist Index; DEA.

\section{EFM Classification code: $\mathbf{5 1 0}$}

${ }^{\dagger}$ Dr Barbara Casu, The University of Reading, Department of Economics, Whiteknights, Reading, RG6 6AH (United Kingdom); Tel. +44(0)118.3786034; e-mail: b.casu@reading.ac.uk.

* Dr Claudia Girardone, University of Essex, Department of Accounting, Finance and Management, Wivenohoe Park, Colchester, CO4 3SQ; Tel. +44(0)1206.874156; Fax: +44(0)1206.873429; e-mail: cgirardone@essex.ac.uk.

* Author that will present the paper 


\section{Introduction}

European deregulation and the introduction of the single market for financial services, together with technological advances, have all played a role in shaping EU banking markets during the 1990s. In recent years, banks have responded to the challenges posed by the new operating environment by developing new products and by creating new forms of intermediation and other fee-based activities. As a result, the traditional business of financing loans by issuing deposits has declined in favour of a significant growth in activities that are not typically captured on banks' balance sheets (Boyd and Gertler, 1994; Siems and Clark, 1997; Rogers and Sinkey, 1999).

The changing nature of bank activities has recently received growing attention from researchers. However, whereas a large number studies, using both econometric and non-parametric models, have examined banks' cost and profit efficiency and productivity change, only a few have explicitly accounted for offbalance-sheet (OBS) business like lines of credit, loan commitments, securitisation and derivatives. Recent studies (see for example, Rogers, 1998; Stiroh, 2000; Clark and Siems, 2002) have argued that omitting OBS in the estimation of bank cost and profit efficiency may result in a misspecification of bank output and lead to incorrect conclusions. However, less is known on the effect that the increase in non-traditional activities has on banks' productivity levels. This paper aims to bridge this gap in the literature by investigating the relevance of the inclusion of OBS business on productivity change in five European banking markets over 1994-2000. 
In particular, using the non-parametric Malmquist methodology this paper investigates the impact of the inclusion of OBS items in the definition of banks output when estimating of total factor productivity change indexes. The analysis is then extended to the decomposition of total factor productivity change into technical efficiency and technological change to assess the impact of the inclusion of OBS items on the main components of productivity growth.

The results reinforce the prevalent view in the recent bank efficiency literature, indicating that the exclusion of non-traditional activities leads to a misspecification of banks output. In particular, the inclusion of OBS items results in an increase in estimated productivity levels for all countries under study. However, the impact seems to be the biggest on technological change rather than efficiency change. Overall, results suggest that despite the uneven distribution of OBS activities between the countries under study and among different banking institutions in the same country, omitting non-traditional activities in the definition of bank output understates productivity levels and may lead to biased conclusions.

The paper is set out as follows: Section 2 reviews the main literature and Section 3 outlines the approaches to the measurement and estimation of productivity change. Section 4 illustrates the results and Section 5 concludes.

\section{A Brief Review of the Relevant Literature}

A handful of US studies begun to include a measure of OBS activities in the specification of banks' output, highlighting that traditional bank efficiency 
measures that exclude OBS items would become less accurate indicators of true bank efficiency. In a study on US commercial banks over 1988-90, Jagtiani et al. (1995) found that the inclusion of OBS products in the cost function has little effect on the scale economies measures. In 1996, Jagtiani and Khathavit included both on- and off- balance sheet activities in a study on large US banks over 198491. They found that following Basle's (1988) prescriptions some of the large banks that previously were efficient became too large and inefficient.

Siems and Clark (1997) estimated bank profit efficiency measures that included OBS activities and found that failing to account for OBS activities has important statistical and economic effects on derived efficiency measures by seriously understating bank output. Rogers (1998) estimated cost, revenue and profit efficiency of US commercial banks by using models with and without OBS items. The author used non-interest income as a proxy for OBS items and employed the distribution free frontier (DFA) estimation method. He found that the standard models that omit OBS items understate bank efficiency. Similarly, Stiroh (2000) found that the efficiency estimates of bank holding companies over 1991-97 are particularly sensitive to output specification and failure to account for OBS activities leads profit efficiency to be understated. In a recent study, Clark and Siems (2002) tested the impact of OBS activities on the measurement of cost and profit X-efficiency in the US banking industry and found strong support for including OBS activities in X-efficiency studies especially on the cost side.

European studies seem to corroborate US results. Rime and Stiroh (2003) examine the performance of large Swiss banks over 1996-99 and found that failure to account for OBS items, trading, and brokerage portfolio management 
activities leads profit efficiency to be dramatically understated. Tortosa-Ausina (2003) examined the importance of non-traditional activities in the analysis of bank cost efficiency for a sample of Spanish banks over 1986-1997. The author finds that average cost efficiency is enhanced when considering an alternative model which includes the OBS items especially for savings banks.

To summarise, most of the studies reviewed here have generally found that the exclusion of OBS items from the efficiency estimations may be misleading to different extents. However, less is known on the effect that the increase on nontraditional activities had on banks productivity levels. As far as we are aware, there are no studies addressing the issue in European banking. This paper aims to bridge this gap in the literature by investigating the relevance of the inclusion of OBS items on the estimation of total factor productivity change.

\section{Methodology and Data}

This section briefly describes the parametric methodological approach followed; it illustrates the sample and discusses the measurement of the inputs and the outputs used in our analysis.

\subsection{Malmquist Total Factor Productivity (TFP) Index}

In the context of this study, total factor productivity (TFP) measures changes in total output relative to inputs and the concept derives from the ideas of Malmquist (1953) ${ }^{1}$ and the distance function approach ${ }^{2}$. Cave et al. (1982b) have investigated productivity indexes derived from Shephard's distance function and 
provided the theoretical framework for the measurement of productivity; this forms the basis for what has become known as the Malmquist Productivity Index number approach. Färe et al $(1985,1994)$ have shown how the Farrell's (1957) efficiency indexes are closely related to Shephard's distance functions ${ }^{3}$.

Total factor productivity (TFP) measures changes in total output relative to inputs and the concept derives from the ideas of Malmquist (1953). The Malmquist TFP index is the most commonly used measure of productivity change. ${ }^{4}$ The Malmquist TFP index measures TFP change between two data points by calculating the ratio of the distances of each data point relative to a common technology. Following Shephard (1970) and Färe et al. (1994) the output distance function is defined ${ }^{5}$ at $t$ as:

$$
\begin{array}{r}
D_{0}^{\mathrm{t}}\left(\mathrm{x}^{\mathrm{t}}, \mathrm{y}^{\mathrm{t}}\right)=\inf \left\{\theta:\left(\mathrm{x}^{\mathrm{t}}, \mathrm{y}^{\mathrm{t}} / \theta\right) \in \mathrm{S}^{\mathrm{t}}\right\} \\
\left.=\left(\sup \left\{\theta: \mathrm{x}^{\mathrm{t}}, \theta \mathrm{y}^{\mathrm{t}}\right) \in \mathrm{S}^{\mathrm{t}}\right\}\right)^{-1}
\end{array}
$$

The distance function seeks the reciprocal of the greatest proportional increase in output, given input, such as output is still feasible. The distance function is the reciprocal of Farrell's (1957) measure of output technical efficiency, which calculates "how far" an observation is from the frontier of technology. To define the Malmquist index, it is necessary to define distance functions with respect to two different time periods:

$$
D_{0}^{t}\left(x^{t+1}, y^{t+1}\right)=\inf \left\{\theta:\left(x^{t+1}, y^{t+1} / \theta\right) \in S^{t}\right\}
$$


This distance function measures the maximum proportional change in outputs required to make $\left(\mathrm{x}^{\mathrm{t}+1}, \mathrm{y}^{\mathrm{t}+1}\right)$ feasible in relation to the technology at $t$.

Following Färe et al. (1994) the Malmquist (output oriented) TFP change index between period $s$ (the base period) and period $t$ is given by:

$$
M_{0}\left(y_{s}, x_{s}, y_{t}, x_{t}\right)=\left[\frac{d_{0}^{s}\left(y_{t}, x_{t}\right)}{d_{0}^{s}\left(y_{s}, x_{s}\right)} \times \frac{d_{0}^{t}\left(y_{t}, x_{t}\right)}{d_{0}^{t}\left(y_{s}, x_{s}\right)}\right]^{1 / 2}
$$

where the notation $d_{0}^{s}\left(x_{t}, y_{t}\right)$ represents the distance from the period $t$ observation to the period $s$ technology. A value of $\mathrm{M}_{0}$ greater than one will indicate positive TFP growth from the period $s$ to period $t$ while a value less than one indicates TFP decline. Note that equation (3) is, in fact, the geometric mean of two TFP indices, the first evaluated with respect to period $s$ technology and the second with respect to period $t$ technology.

An equivalent way of writing the index is:

$$
M_{0}\left(y_{s}, x_{s}, y_{t}, x_{t}\right)=\frac{d_{0}^{t}\left(y_{t}, x_{t}\right)}{d_{0}^{s}\left(y_{s}, x_{s}\right)}\left[\frac{d_{0}^{s}\left(y_{t}, x_{t}\right)}{d_{0}^{t}\left(y_{t}, x_{t}\right)} \times \frac{d_{0}^{s}\left(y_{s}, x_{s}\right)}{d_{0}^{t}\left(y_{s}, x_{s}\right)}\right]^{1 / 2}
$$

where the ratio outside the square brackets measures the change in the output oriented measure of Farrell technical efficiency between period $s$ and $t$. That is, the efficiency change is equivalent to the ratio of the Farrell technical efficiency in period $t$ to the Farrell technical efficiency in period $s$. The remaining part of the index in equation (4) is a measure of technical change. It is the geometric mean of 
the shift in technology between the two periods, evaluated at $x_{t}$ and $x_{s}$. Therefore,

$$
\begin{array}{cc}
\mathrm{M}_{0}\left(\mathrm{y}_{\mathrm{s}}, \mathrm{x}_{\mathrm{s}}, \mathrm{y}_{\mathrm{t}}, \mathrm{x}_{\mathrm{t}}\right)=\frac{d_{0}^{t}\left(y_{t}, x_{t}\right)}{d_{0}^{s}\left(y_{s}, x_{s}\right)} \times & \text { (Efficiency change) } \\
{\left[\frac{d_{0}^{s}\left(y_{t}, x_{t}\right)}{d_{0}^{t}\left(y_{t}, x_{t}\right)} \times \frac{d_{0}^{s}\left(y_{s}, x_{s}\right)}{d_{0}^{t}\left(y_{s}, x_{s}\right)}\right]^{1 / 2}} & \quad \text { (Technological change) }
\end{array}
$$

Productivity change $\left(\mathrm{M}_{0}\right)$ is decomposed into Technological Change (TC), which reflects improvement or deterioration in the performance of best practice Decision Making Units (DMUs); and Technical Efficiency Change (TEC), which reflects the convergence towards or divergence from the best practice on part of the remaining DMUs. The value of the decomposition is that it provides information on the sources of the overall productivity change. Several different methods can be used to compute the distance functions which compose the Malmquist TFP index; to date, the most popular method has been the DEA-like programming method suggested by Färe et al. (1994), which is the method that will be followed in our empirical analysis.

\subsection{Data and Inputs and Outputs Definition}

Our data set is primarily drawn from BankScope and includes annual information for a balanced panel of over 2000 European banks between 1994 and 2000. The sample comprises only large banks (total assets $>$ Euro 450 million) from the largest European banking markets: France (357 banks), Germany (518 
banks), Italy (413 banks), Spain (448 banks) and United Kingdom (350 banks). Subsidiaries of foreign banks, specialised financial institutions and central institutions as well as all banks particular to a certain country (for example, special credit institutions in Italy, finance companies in France and official credit institutions in Spain) were excluded from the sample. As in Stiroh (2000) the sample comprises only continuously operating institutions, to avoid the impact of entry and exit and so as to focus on the behaviour of a core of large European banks during the 1990s. Estimations are carried out on individual countries.

The approach to output definition used in this study is a variation of the intermediation approach, which was originally developed by Sealey and Lindley (1977) and posits that total loans and securities are outputs, whereas deposits along with labour and physical capital are inputs. Specifically, the input vector used in this study are proxies for cost of labour (personnel expenses); the cost of deposits (interest expenses) and the cost of capital (total operating expenses) Hence the total costs include both interest expense and operating costs and are proxied by the sum of labour, capital and loanable funds expenditures. All input prices are calculated as flows over the year, divided by these stocks: cost of labour (personnel expenses/total assets); deposits (interest expenses/customer and shortterm funding) and capital (total capital expenses/total fixed assets).

The output variables capture both the traditional lending activity of banks (total loans) and the growing non-lending activities (securities). In addition, we also include the nominal value of banks' off-balance sheet items as a third output. Clark and Siems (2002) propose three alternative measures of a bank's aggregate OBS: the first measure is the total credit equivalent amount of OBS transactions, 
constructed following the Basle guidelines. The second measure, originally proposed by Boyd and Gertler (1994) is an aggregate measure of asset equivalent that utilises the rate of return on balance-sheet items to capitalise the non-interest income from OBS activities. The third proxy is non-interest income, based on the assumption that for larger banks this is mainly generated by OBS.

All three measures have drawbacks. The Basle credit-equivalent measure may seriously underestimate the level of OBS (Boyd and Gertler, 1994; Clark and Siems, 2002). The asset equivalent measure is a revenue based measure that include losses and this could potentially distort the measure of OBS. Furthermore, as highlighted by Clark and Siems (2002) OBS such as derivatives may be used for hedging other on balance sheet risks and therefore the symmetry assumption of equal profitability between on and off-balance sheet items could also contribute to a distortion in the measure. Finally, non-interest income may overestimate the amount of OBS, since fees and commissions are drawn also from on-balance sheet activities.

In this study, we employ the nominal value of banks' OBS items as an output measure, together with the nominal value of loans and other earning assets.

\section{$<$ Table 1 here $>$}

Table 1 shows substantial variation in the financial characteristics of the sample banks. Spanish and Italian banks have, on average, the smallest balance sheets in our sample and among the lowest level of OBS activity. Staff costs are the lowest in the UK, whereas interest costs appear to be highest in Italy. On 
average, the UK and French banks in our sample are substantially larger than those in the other countries under study. Although not shown Table 1, the nominal value of OBS items stood at a lower level in 2000 than compared with 1994 for all the systems under study.

\section{4. $\underline{\text { Results }}$}

The importance of including OBS activities in the output definition to estimate banks TFP change is examined in two ways. The first approach examines the correlation between TFP estimates obtained with and without OBS at country level and tests for differences between mean TFP estimates when the OBS measure is first excluded and then included from the analysis. Then ranking differences are investigated to identify the impact of the inclusion/exclusion of OBS items on individual institutions in each country.

Following Färe et al. (1994) the Malmquist (output-oriented) TFP change index has been calculated. A value of the index greater than one indicates positive TFP growth while a value less than one indicates TFP decline over the period. Productivity change is then decomposed into Technological Change (TC), and Technical Efficiency Change (TEC), where TFP = TC x TEC. An improvement in TC is considered as a shift in the best practice frontier, whereas an improvement in TEC is the "catch up" term.

Productivity change estimates are summarised below. The annual entries in each column in Table 2 are geometric means of results for individual banks and the period results reported in the last row for each country are geometric means of the annual geometric means. 
$<$ Table 2 here $>$

From Table 2 it is possible to note that, when the estimations are carried out without the inclusion of OBS items in the banks output specification, the TFP index for the French and German banking sectors shows a slight decrease over the 1994-00 period $(-1.6 \%$ and $-2.8 \%$ respectively). The results relative to both banking systems suggest deterioration in the performance of best practice banks, as indicated by Technological Change indices smaller that unity. An interesting feature is the catching up with best practice institutions (efficiency change of $+4.5 \%$ ) for German banks, whereas French banks seem to display deterioration also in the cost efficiency levels.

The results relative to the Italian and UK banking sectors show an improvement in the TFP index with an overall increase in productivity of about $6.9 \%$ and $1.2 \%$ respectively. This productivity growth seems to have been brought about by both a positive technological change $(+3.5 \%)$ and increase in efficiency $(+3.3)$ in the Italian banking system, whereas TFP growth in the UK seem to be mainly explained by positive technological change rather then by improvements in efficiency. On the contrary, the improvement in technological change in the Spanish banking sector $(+1.9)$ was not enough to contrast a decrease in productive efficiency $(-2 \%)$ over the period, therefore resulting in an almost constant rate of productivity change.

When OBS items are added to the definition of banking output, a different picture seems to emerge. Overall, there seems to be TFP growth for all countries 
under analysis, with a particularly important change in direction of the index in the case of Spanish banks, which now indicates TFP growth of $+9.5 \%$. The introduction of OBS items in the definition of bank output seems to have impacted the most on technological change, which increased with respect to the previous estimation for most countries in the sample (for example, for Spanish banks technological change increased from +1.9 without OBS to +9.2 with $\mathrm{OBS}$; in France it increased from $-0.7 \%$ to $+3.1 \%$ ). These results can be justified by the assumption that those banks that are "shifting the frontier" are more likely to have a substantial OBS portfolio and would have been penalised the most if such output had not been included in the analysis.

To test the statistical significance of such differences, Table 3 presents the results of a series of t-test of the null hypothesis that the mean estimated productivity changes, and its components, are the same whether OBS activities are included or excluded from the output specification.

$<$ Table 3 here $>$

The results shown in Table 3 indicate that the null hypothesis of no difference in estimated productivity change, or in its components, can be rejected in 11 of 15 instances. Furthermore, in the case of the UK, where the null hypothesis could be accepted in all instances, that is there is not a statistically significant difference between the two groups, the power of the test is below the desired level and therefore such results should be interpreted with caution. In all cases where the null hypothesis can be rejected, the estimated mean productivity 
change increases when OBS are included in the output specification, thus reinforcing the view prevalent in the recent literature that the exclusion of OBS items leads to underestimation of productivity levels. However, when analysing the components of productivity change, whereas in all instances mean technological change increases when OBS are included as an output variable, in three cases efficiency change results deteriorate.

Table 4 shows the results of the Mann-Whitney rank sum test, which reinforces the evidence presented in Table 3.

$<$ Table 4 here $>$

Again, the null hypothesis that the differences in the median values between the groups are greater than we would expect by chance is rejected in 10 of 15 instances. A closer analysis of the impact of OBS items points to country differences. Correlation analyses of individual bank's TFP index with and without the introduction of OBS in the output specification are positive and statistically significant at the 0.01 level for all countries with the exception of the $\mathrm{UK}^{6}$. From these results is possible to infer that for UK banks OBS activities are relatively more important than in Italy and Germany. Indeed, this reflects the different magnitude and trend of the OBS/Total Asset (OBS/TA) ratios for the whole banking sector. For example, in the year 2000, the ratio OBS/TA was around 35\% in the UK and $13 \%$ in Italy $^{7}$. However, while in the UK the ratio shows a constantly increasing trend over the 1994-00 period; it sharply decreased in Italy, 
where banks have been concentrating mainly on asset management as a non traditional source of income.

$<$ Table 5 here $>$

To consider the impact of omitting OBS items on individual institutions, we analyse the ranking differences, that is how much an institution betters (or worsen) its rank position under the two output specifications. The results are illustrated in Figure 1. Italian and German banks are displaying the biggest changes in ranking between the two models. This indicates that, whereas on average the TFP growth of Italian and German banks is not greatly affected by OBS items, for a number of institutions the results change dramatically. These findings are in line with the structure of the relative banking sectors: the Italian and German banking systems are indeed the least concentrated within the countries in our sample (the 5-firm concentration ratio (CR-5) is equal to 23 and 20 respectively) with a handful of big universal institutions competing globally and a high number of small sized banks which are still concentrated on traditional lending business.

Overall, results suggest that despite the uneven distribution of OBS between countries and among different institutions in the same country, these nontraditional activities are increasingly important and failure to account for them would lead to biased conclusions. 


\section{Conclusion}

Banks' responses to the changing nature of the operating environment have resulted in changes in the structure of their financial accounts and are mainly reflected in the increase of OBS activities. Using the non-parametric Malmquist methodology this paper attempts to investigate to what extent the inclusion of OBS items in the output definition of banks affect the estimated total factor productivity change indexes. The inclusion of OBS items seems to impact the most on technological change rather than efficiency change. This indicates that banks that are "shifting the frontier" are more likely to have a substantial OBS portfolio and would have been penalised the most if such output had not been included in the analysis. Overall, the results suggest that despite the uneven distribution of OBS activities between the countries under study and among

different banking institutions in the same country, omitting non-traditional activities in the definition of bank output understates productivity levels and may lead to biased conclusions. 


\section{References}

Boyd, J.H. and M. Gertler (1994) Are Banks Dead? Or are the Reports Greatly Exaggerated?, Federal Reserve Bank of Minneapolis Quarterly Review, Vol. 18,3 , Summer.

Caves, D.W., Christensen, L.R. and W.E. Diewert (1982a) Multilateral Comparisons of Output, Input and Productivity Using Superlative Index Numbers, Economic Journal, 92, 73-86.

Caves, D.W., Christensen, L.R. and W.E Diewert (1982b) The Economic theory of Index Numbers and the Measurement of Input, Output and Productivity, Econometrica, 50, 1393-1414.

Clark, J.A. and T.F. Siems (2002) X-Efficiency In Banking: Looking Beyond the Balance Sheet, Journal of Money, Credit and Banking, Vol. 34, 4, November, 987-1013.

Diewert, W.E. (1976) Exact and Superlative Index Numbers, Journal of Econometrics, 4, 115-145.

Diewert, W.E. (1978) Superlative Index Numbers and Consistency in Aggregation, Econometrica, 46, 883-900.

Diewert, W.E. (1981) The Economic Theory of Index Numbers: A Survey, in: Deaton A. (Ed.), Essays in the Theory and Measurement of Consumer Behaviour (in honour of Richard Stone). Cambridge University Press, New York, 163-208.

ECB (2003) EU Banking Sector Stability, European Central Bank Publication, Frankfurt, February.

ECB (2000) EU Banks' Income Structure, European Central Bank Publication, Frankfurt, April.

Färe, R. Grosskopf, S. and C.A.K. Lovell (1985) The measurement of Efficiency of Production, Kluwer Academic Publishers, Boston.

Färe, R. Grosskopf, S. and C.A.K. Lovell (1994) Production Frontiers, Cambridge University Press, Cambridge.

Färe, R. Grosskopf, S. and P. Roos (1997) Malmquist Productivity Indexes: A Survey of Theory and Practice, in: Färe, R., Grosskopf, S., Russell, R.R. (Eds.), Index Numbers: Essays in Honour of Sten Malmquist, Kluwer Academic Publishers, Boston.

Farrell, M.J. (1957) The Measurement of Productive Efficiency, Journal of Royal Statistical Society, 120, 253-281.

Grosskopf, S. (1993) Efficiency and Productivity, in: Fried, H.O., Lovell, C.A.K., Schmidt, S.S. (Eds.), The Measurement of Productive Efficiency: Techniques and Applications, Oxford University Press, UK.

Jagtiani, J. and A. Khanthavit (1996) Scale and Scope Economies at Large Banks: Including Off-Balance Sheet Products and Regulatory Effects (1984-1991), Journal of Banking and Finance, 20, 1271-1287.

Jagtiani, J. Nathan, A. and G. Sick (1995) Scale Economies and Cost Complementarities in Commercial Banks: On and Off-Balance Sheet Activities, Journal of Banking and Finance, 19, 1175-1189.

Malmquist, S. (1953) Index Numbers and Indifference Surfaces, Trabajos de Estatistica, 4, 209-42. 
Mukherjee, K, Ray, S.C and S.M. Miller (2001) Productivity Growth in Large US Banks: The Initial Post-Deregulation Experience, Journal of Banking \& Finance, Vol. 25, 5, 913-939.

Rime, B. and K.J. Stiroh (2003) The Performance of Universal Banks: Evidence from Switzerland, Journal of Banking and Finance, Vol. 27, 11, 2121 2150.

Ray, S.C. and E. Desli (1997) Productivity Growth, Technical Progress, and Efficiency Change in Industrialised Countries: Comment, The American Economic Review, 87, 5, 1033-1039.

Rogers, K.E. (1998) Non-traditional Activities and the Efficiency of US Commercial Banks, Journal of Banking and Finance, 22, 467-482.

Rogers, K.E. and J.F. Sinkey (1999) An Analysis of Nontraditional Activities at US Commercial Banks, Review of Financial Economics, Vol. 8, 1, June, 2539.

Sealey, C.W. and J.T. Lindley (1977) Inputs, Outputs and a Theory of Production and Cost at Depository Financial Institutions, Journal of Finance, 32, 12511266.

Shephard, R.W. (1970) Theory of Cost and Production Functions, Princeton N.J., Princeton University Press.

Siems, T.F. and J.A. Clark (1997) Rethinking Bank Efficiency and Regulation: How Off-Balance Sheet Activities Make a Difference, Financial Industry Studies, Federal Reserve Bank of Dallas, 1-11.

Stiroh, K.J. (2000) How Did Bank Holding Companies Prosper in the 1990s? Journal of Banking and Finance, Vol. 24, 11, 1703-1745.

Tortosa-Ausina, E. (2003) Nontraditional Activities and Bank Efficiency Revisited: A Distributional Analysis for Spanish Financial Institutions, Journal of Economics and Business, 55, 371-395. 
Table 1 Summary Statistics on Cost, Output Quantities and Input
Prices (Pooled Data 1994-00)

\begin{tabular}{|c|c|c|c|c|c|c|c|c|}
\hline & & $\overline{T C}$ & $\overline{\mathrm{Q} 1}$ & $\overline{\text { Q2 }}$ & Q3 & $\mathrm{P} 1$ & $\overline{\mathrm{P} 2}$ & $\mathrm{P3}$ \\
\hline \multirow[t]{5}{*}{ FRANCE } & mean & 1543.29 & 9384.46 & 12296.59 & 10868.14 & 0.014 & 0.060 & 1.577 \\
\hline & median & 324.30 & 2280.90 & 2350.10 & 799.90 & 0.012 & 0.049 & 1.197 \\
\hline & $\min$ & 120.40 & 158.70 & 311.50 & 13.50 & 0.001 & 0.017 & 0.186 \\
\hline & $\max$ & 34527.10 & 177569.50 & 269369.30 & 289092.90 & 0.035 & 0.342 & 6.449 \\
\hline & stdev & 4004.54 & 24300.33 & 32488.29 & 33598.06 & 0.006 & 0.037 & 1.159 \\
\hline \multirow[t]{5}{*}{ GERMANY } & mean & 584.92 & 6018.75 & 5188.25 & 1727.24 & 0.011 & 0.044 & 0.848 \\
\hline & median & 270.80 & 3005.65 & 1951.10 & 363.70 & 0.011 & 0.043 & 0.435 \\
\hline & $\min$ & 110.40 & 542.40 & 498.90 & 0.10 & 0.002 & 0.023 & 0.149 \\
\hline & $\max$ & 15391.70 & 156541.30 & 175442.80 & 67430.40 & 0.018 & 0.101 & 17.333 \\
\hline & stdev & 1318.14 & 12998.40 & 15752.98 & 6772.04 & 0.003 & 0.011 & 1.448 \\
\hline \multirow[t]{5}{*}{ ITALY } & mean & 683.88 & 5109.17 & 4134.75 & 2639.02 & 0.019 & 0.066 & 0.661 \\
\hline & median & 225.50 & 1472.00 & 1388.50 & 493.60 & 0.018 & 0.067 & 0.564 \\
\hline & $\min$ & 56.90 & 172.90 & 182.30 & 26.00 & 0.008 & 0.013 & 0.114 \\
\hline & $\max$ & 7282.90 & 57032.30 & 43729.50 & 77360.00 & 0.032 & 0.208 & 7.121 \\
\hline & stdev & 1222.68 & 9232.18 & 7445.60 & 7680.41 & 0.004 & 0.029 & 0.468 \\
\hline \multirow[t]{5}{*}{ SPAIN } & mean & 387.42 & 3596.26 & 2718.57 & 429.72 & 0.016 & 0.044 & 0.359 \\
\hline & median & 189.90 & 1874.55 & 1194.30 & 126.60 & 0.016 & 0.039 & 0.284 \\
\hline & $\min$ & 8.70 & 17.10 & 24.60 & 1.00 & 0.001 & 0.012 & 0.085 \\
\hline & $\max$ & 4680.60 & 44441.00 & 31340.30 & 10834.90 & 0.189 & 1.390 & 2.453 \\
\hline & stdev & 631.52 & 5487.90 & 4650.05 & 933.51 & 0.009 & 0.066 & 0.259 \\
\hline \multirow[t]{5}{*}{$U K^{b}$} & mean & 1626.37 & 16478.88 & 10741.71 & 43358.89 & 0.007 & 0.056 & 0.548 \\
\hline & median & 43.10 & 587.90 & 143.90 & 9036.50 & 0.007 & 0.055 & 0.498 \\
\hline & $\min$ & 2.90 & 37.10 & 3.30 & 0.00 & 0.003 & 0.028 & 0.133 \\
\hline & $\max$ & 26047.60 & 283738.40 & 197671.40 & 183492.40 & 0.018 & 0.096 & 2.000 \\
\hline & stdev & 4434.96 & 43585.99 & 33285.81 & 54959.76 & 0.003 & 0.009 & 0.255 \\
\hline
\end{tabular}

${ }^{\mathrm{a}} \mathrm{TC}=$ total costs $\left(€\right.$ mil.); $\mathrm{Q}_{1}=$ total loans $\left(€\right.$ mil.); $\mathrm{Q}_{2}=$ other earning assets $\left(€\right.$ mil.); $\mathrm{Q}_{3}=$ off-balance sheet activities nominal value $\left(€\right.$ mil.); $\mathrm{P}_{1}=$ personnel expenses/total assets; $\mathrm{P}_{2}=$ interest expenses/total customer deposits; $\mathrm{P}_{3}=$ other non-interest expenses/total fixed assets.

${ }^{\mathrm{b}}$ In the UK, the sample is 50 banks per year (over the 7-year period: 350 banks) of which 6 banks per year have published offbalance sheet activities (over the 7-year period: 42 ). 
Table 2: Malmquist Index Decomposition (Summary of Annual Means) $^{a, b}$

\begin{tabular}{|c|c|c|c|c|c|c|c|}
\hline & & \multicolumn{3}{|c|}{ WITHOUT OBS } & \multicolumn{3}{|c|}{ WITH OBS } \\
\hline & & $\begin{array}{l}\text { EFFICIENCY } \\
\text { CHANGE }\end{array}$ & $\begin{array}{c}\text { TECHNOLOGICAL } \\
\text { CHANGE }\end{array}$ & $\begin{array}{c}\text { TOTAL FACTOR } \\
\text { PRODUCTIVITY } \\
\text { CHANGE }\end{array}$ & $\begin{array}{l}\text { EFFICIENCY } \\
\text { CHANGE }\end{array}$ & $\begin{array}{c}\text { TECHNOLOGICAL } \\
\text { CHANGE }\end{array}$ & $\begin{array}{c}\text { TOTAL FACTOR } \\
\text { PRODUCTIVITY } \\
\text { CHANGE }\end{array}$ \\
\hline \multirow[t]{6}{*}{ FRANCE } & $1994 / 95$ & 1.044 & 0.934 & 0.975 & 1.076 & 0.903 & 0.972 \\
\hline & $1995 / 96$ & 0.943 & 1.014 & 0.956 & 0.938 & 1.155 & 1.084 \\
\hline & $1996 / 97$ & 1.042 & 0.923 & 0.961 & 0.944 & 1.090 & 1.028 \\
\hline & $1997 / 98$ & 0.931 & 1.054 & 0.981 & 1.010 & 0.989 & 0.999 \\
\hline & 1998/99 & 1.037 & 0.957 & 0.993 & 0.935 & 1.162 & 1.086 \\
\hline & $1999 / 00$ & 0.955 & 1.086 & 1.038 & 1.030 & 0.921 & 0.949 \\
\hline Mean & $1994 / 00$ & 0.991 & 0.993 & 0.984 & 0.987 & 1.031 & 1.018 \\
\hline \multirow[t]{6}{*}{ GERMANY } & $1994 / 95$ & 0.952 & 0.970 & 0.923 & 1.045 & 0.919 & 0.960 \\
\hline & $1995 / 96$ & 1.089 & 0.914 & 0.995 & 1.027 & 1.040 & 1.068 \\
\hline & $1996 / 97$ & 0.793 & 1.186 & 0.940 & 1.019 & 1.017 & 1.036 \\
\hline & $1997 / 98$ & 1.111 & 0.849 & 0.943 & 1.033 & 0.949 & 0.980 \\
\hline & 1998/99 & 1.341 & 0.787 & 1.055 & 1.005 & 1.067 & 1.073 \\
\hline & $1999 / 00$ & 1.064 & 0.926 & 0.985 & 0.982 & 0.947 & 0.930 \\
\hline Mean & $1994 / 00$ & 1.045 & 0.931 & 0.972 & 1.018 & 0.988 & 1.006 \\
\hline \multirow[t]{6}{*}{ ITALY } & $1994 / 95$ & 0.961 & 1.005 & 0.965 & 0.982 & 0.965 & 0.948 \\
\hline & $1995 / 96$ & 1.088 & 0.890 & 0.968 & 0.995 & 1.042 & 1.037 \\
\hline & $1996 / 97$ & 1.173 & 0.901 & 1.057 & 1.025 & 1.144 & 1.173 \\
\hline & $1997 / 98$ & 0.954 & 1.198 & 1.142 & 0.987 & 1.211 & 1.195 \\
\hline & 1998/99 & 1.042 & 1.103 & 1.149 & 0.968 & 1.320 & 1.278 \\
\hline & $1999 / 00$ & 0.995 & 1.158 & 1.152 & 0.954 & 0.992 & 0.947 \\
\hline Mean & $1994 / 00$ & 1.033 & 1.035 & 1.069 & 0.985 & 1.105 & 1.089 \\
\hline \multirow[t]{6}{*}{ SPAIN } & $1994 / 95$ & 0.925 & 1.009 & 0.933 & 1.040 & 0.928 & 0.965 \\
\hline & $1995 / 96$ & 1.035 & 0.981 & 1.015 & 1.009 & 1.064 & 1.074 \\
\hline & $1996 / 97$ & 1.080 & 0.988 & 1.067 & 0.884 & 1.408 & 1.244 \\
\hline & $1997 / 98$ & 0.915 & 1.060 & 0.970 & 1.100 & 1.064 & 1.170 \\
\hline & 1998/99 & 1.010 & 1.027 & 1.037 & 0.993 & 1.226 & 1.217 \\
\hline & $1999 / 00$ & 0.931 & 1.049 & 0.976 & 1.003 & 0.934 & 0.937 \\
\hline Mean & $1994 / 00$ & 0.980 & 1.019 & 0.999 & 1.003 & 1.092 & 1.095 \\
\hline \multirow[t]{6}{*}{ UK } & $1994 / 95$ & 1.016 & 0.949 & 0.965 & 1.087 & 0.878 & 0.954 \\
\hline & $1995 / 96$ & 0.972 & 1.126 & 1.095 & 0.985 & 1.073 & 1.057 \\
\hline & $1996 / 97$ & 0.963 & 1.011 & 0.973 & 0.961 & 1.072 & 1.029 \\
\hline & $1997 / 98$ & 1.040 & 0.869 & 0.904 & 1.045 & 0.929 & 0.971 \\
\hline & 1998/99 & 1.023 & 1.175 & 1.202 & 0.965 & 1.071 & 1.033 \\
\hline & $1999 / 00$ & 0.978 & 0.976 & 0.955 & 1.046 & 0.972 & 1.017 \\
\hline Mean & $1994 / 00$ & 0.998 & 1.012 & 1.011 & 1.014 & 0.996 & 1.010 \\
\hline
\end{tabular}

${ }^{a}$ Note: A number $<1$ indicates decline; a number $>1$ indicates growth.

${ }^{\mathrm{b}} \mathrm{TEC} \times \mathrm{TC}=\mathrm{TFP}$ 
Table 3: t-test for Differences between measures of Malmquist TFP

\begin{tabular}{|c|c|c|c|c|}
\hline & & $\begin{array}{l}\text { EFFICIENCY } \\
\text { CHANGE }\end{array}$ & $\begin{array}{c}\text { TECHNOLOGICAL } \\
\text { CHANGE }\end{array}$ & $\begin{array}{c}\text { TOTAL FACTOR } \\
\text { PRODUCTIVITY } \\
\text { CHANGE }\end{array}$ \\
\hline \multicolumn{5}{|l|}{ FRANCE } \\
\hline & without OBS & 0.9933 & 0.994 & 0.9876 \\
\hline & with OBS & 0.9879 & 1.032 & 1.0197 \\
\hline & mean & 0.0054 & -0.038 & -0.0321 \\
\hline & t-Statistic & 0.559 & -6.171 & -0.3026 \\
\hline & Sig. (two-tailed) & 0.578 & 0.000 & 0.004 \\
\hline \multicolumn{5}{|c|}{ GERMANY } \\
\hline & without OBS & 1.0469 & 0.9325 & 0.9773 \\
\hline & with OBS & 1.0184 & 0.9903 & 1.0087 \\
\hline & mean & 0.0284 & -0.578 & -0.315 \\
\hline & t-Statistic & -18.34 & -5.31 & 5.768 \\
\hline & Sig. (two-tailed) & 0.000 & 0.000 & 0.000 \\
\hline \multicolumn{5}{|l|}{ ITALY } \\
\hline & without OBS & 1.0344 & 1.0356 & 1.0709 \\
\hline & with OBS & 0.9855 & 1.1056 & 0.0894 \\
\hline & mean & 0.0489 & -0.07 & -0.184 \\
\hline & t-Statistic & -16.841 & -2.396 & -1.997 \\
\hline & Sig. (two-tailed) & 0.000 & 0.000 & 0.020 \\
\hline \multicolumn{5}{|l|}{ SPAIN } \\
\hline & without OBS & 0.984 & 1.0201 & 1.0037 \\
\hline & with OBS & 1.003 & 1.0925 & 1.0957 \\
\hline & mean & -0.0189 & -0.0724 & -0.92 \\
\hline & t-Statistic & -15.721 & -8.835 & -2.261 \\
\hline & Sig. (two-tailed) & 0.050 & 0.000 & 0.000 \\
\hline \multicolumn{5}{|l|}{ UK } \\
\hline & without OBS & 0.09867 & 0.9902 & 0.9772 \\
\hline & with OBS & 1.0138 & 0.9968 & 1.011 \\
\hline & mean & -0.0272 & -0.0067 & -0.338 \\
\hline & t-Statistic & -2.261 & -0.409 & -1.503 \\
\hline & Sig. (two-tailed) & 0.073 & 0.700 & 0.193 \\
\hline
\end{tabular}


Table 4: Mann-Whitney Rank Sum Test

\begin{tabular}{|c|c|c|c|c|c|}
\hline & & & $\begin{array}{c}\text { EFFICIENCY } \\
\text { CHANGE }\end{array}$ & $\begin{array}{c}\text { TECHNOLOGICAL } \\
\text { CHANGE }\end{array}$ & $\begin{array}{c}\text { TOTAL FACTOR } \\
\text { PRODUCTIVITY } \\
\text { CHANGE }\end{array}$ \\
\hline \multicolumn{6}{|l|}{$\overline{\text { FRANCE }}$} \\
\hline & without OBS & & 0.996 & 1.003 & 0.99 \\
\hline & with OBS & & 0.994 & 1.036 & 1.022 \\
\hline & & $H_{o}$ & Accepted & Rejected & Rejected \\
\hline & t-Statistic & & 2661 & 1858 & 2230 \\
\hline & P-value & & 0.820 & $<0.001$ & 0.008 \\
\hline \multicolumn{6}{|l|}{ GERMANY } \\
\hline & without OBS & & 1.044 & 0.933 & 0.982 \\
\hline & with OBS & & 1.024 & 0.998 & 1.023 \\
\hline & & $H_{0}$ & Rejected & Rejected & Rejected \\
\hline & t-Statistic & & 6502 & 3104 & 4553 \\
\hline & P-value & & $<0.001$ & $<0.001$ & $<0.001$ \\
\hline \multicolumn{6}{|l|}{ ITALY } \\
\hline & without OBS & & 1.035 & 1.033 & 1.075 \\
\hline & with OBS & & 0.99 & 1.107 & 1.09 \\
\hline & & $H_{o}$ & Rejected & Rejected & Accepted \\
\hline & t-Statistic & & 4615 & 1845 & 3183 \\
\hline & P-value & & $<0.001$ & $<0.001$ & 0.078 \\
\hline \multicolumn{6}{|l|}{ SPAIN } \\
\hline & without OBS & & 0.977 & 1.017 & 0.99 \\
\hline & with OBS & & 1 & 1.1 & 1.099 \\
\hline & & $H_{o}$ & Rejected & Rejected & Rejected \\
\hline & t-Statistic & & 3547 & 2664 & 2789 \\
\hline & P-value & & 0.006 & $<0.001$ & $<0.001$ \\
\hline \multicolumn{6}{|l|}{ UK } \\
\hline & without OBS & & 0.994 & 1.008 & 0.992 \\
\hline & with OBS & & 1.004 & 0.997 & 1.014 \\
\hline & & $H_{0}$ & Accepted & Accepted & Accepted \\
\hline & t-Statistic & & 27 & 38 & 34 \\
\hline & $P$-value & & 0.065 & 0.937 & 0.485 \\
\hline
\end{tabular}


Table 5: Correlation Analysis

\begin{tabular}{|c|c|c|c|c|}
\hline & & $\begin{array}{c}\text { EFFICIENCY } \\
\text { CHANGE }\end{array}$ & $\begin{array}{c}\text { TECHNOLOGICAL } \\
\text { CHANGE }\end{array}$ & $\begin{array}{c}\text { TOTAL FACTOR } \\
\text { PRODUCTIVITY } \\
\text { CHANGE } \\
\end{array}$ \\
\hline \multicolumn{5}{|l|}{ FRANCE } \\
\hline & Pearson & $0.298^{*}$ & $0.553^{\star \star}$ & $0.535^{\star \star}$ \\
\hline & Spearman's rho & $0.352^{*}$ & $0.335^{*}$ & $0.499^{* *}$ \\
\hline \multicolumn{5}{|c|}{ GERMANY } \\
\hline & Pearson & 0.210 & $0.867^{* *}$ & $0.813^{\star *}$ \\
\hline & Spearman's rho & $0.281^{*}$ & 0.014 & $0.426^{* *}$ \\
\hline \multicolumn{5}{|l|}{ ITALY } \\
\hline & Pearson & 0.320 & -0.253 & $0.366^{* *}$ \\
\hline & Spearman's rho & 0.032 & 0.110 & $0.309^{*}$ \\
\hline \multicolumn{5}{|l|}{ SPAIN } \\
\hline & Pearson & $0.606^{* *}$ & $0.751^{* *}$ & $0.623^{* *}$ \\
\hline & Spearman's rho & $0.485^{\star *}$ & $0.695^{\star *}$ & $0.626^{* *}$ \\
\hline \multicolumn{5}{|l|}{ UK } \\
\hline & Pearson & 0.056 & 0.733 & 0.607 \\
\hline & Spearman's rho & -0.059 & 0.429 & 0.429 \\
\hline
\end{tabular}

* indicates significant at the 0.05 level

** indicates significant at the 0.01 level. 
Figure 1: Absolute Ranking Differences

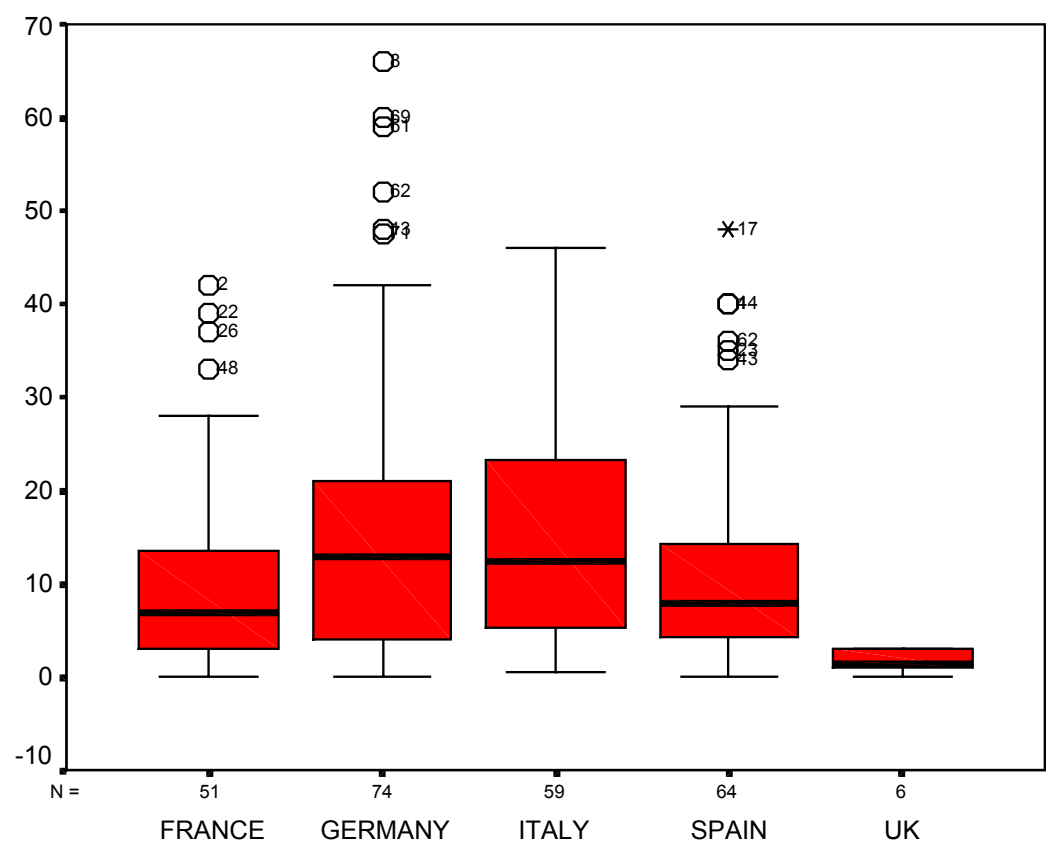




\section{Footnotes}

\footnotetext{
${ }^{1}$ Important developments in this field have been introduced, among others, by the work of Diewert (1976, 1978, 1981), Caves, Christensen and Diewert (1982a and 1982b) and Färe, Grosskopf and Lovell $(1985,1994)$.

${ }^{2}$ Shephard's (1970) distance functions have guided much of the development in efficiency and productivity analysis. In a multi-input multi-output framework, an output distance function is defined as the reciprocal of the maximum proportional expansion of the output vector, given inputs. An input distance function is defined as the reciprocal of the maximum proportional contraction of the input vector, given outputs.

${ }^{3}$ In his empirical work, Farrell (1957) defines technical efficiency as the maximum proportional contraction of inputs. He also indicated that, under constant returns to scale, this may be interpreted as the percentage by which output could be increased using the same inputs. The interpretation of Farrell's measures of technical efficiency as reciprocals of distance functions can be found in Färe et al. (1985, 1994).

${ }^{4}$ For a literature survey on the subject, see Grosskopf (1993) and Färe, Grosskopf and Roos (1997). Also, Ray and Desli (1997) discuss the conceptual framework and Mukherjee, Ray and Miller (2001) derive the geometric decomposition for a generalised Malmquist index.

${ }^{5}$ The input distance function is similarly defined.

${ }^{6}$ It is to note that data on OBS items for UK banks were available on for 6 institutions, namely HSBC, Barclays Bank, Clydesdale Bank, Abbey National, NatWest and the Royal Bank of Scotland.

7 Specifically, according to ECB (2000 and 2003) the OBS/Total Assets ratio for the whole banking sectors in the year 1994 (2000) was: 28.31 (29.76) in France, 14.54 (13.46) in Germany, 24.91 (13.46) in Italy, 5.65 (9.66) in Spain and 32.53 (34.2) in the UK.
} 